\title{
THE EFFECT OF ANTEROMEDIAN SPHINCTEROTOMY ON PENILE ERECTIONS IN PATIENTS WITH NEUROPATHIC BLADDER
}

\author{
By N. H. Philp, F.R.C.S., ${ }^{1}$ D. G. Thomas, F.R.C.S. ${ }^{2}$ and A. M. K. \\ Rickwood, F.R.C.S. ${ }^{3}$ \\ ${ }^{1}$ Senior Registrar, Department of Urology, The General Infirmary, Leeds. ${ }^{2}$ Con- \\ sultant Urologist, ${ }^{3}$ Consultant, Spinal Injuries Unit, Lodge Moor Hospital, Sheffield \\ $S_{I O} 4 L H$.
}

Summary. In a series of 94 patients with neuropathic bladder undergoing anteromedian urethral sphincterotomy, 20 had no penile erections prior to surgery. In the remaining 74 cases, seven $(9.5$ per cent $)$ had diminished erections postoperatively and three (4 per cent) no erections. It is considered that the risk of this complication is less with anteromedian sphincterotomy than with bilateral 3 and 9 o'clock sphincterotomy.

Key words: Neuropathic bladder; Penile erections; Urethral sphincterotomy.

\section{Introduction}

ENDOSCOPIC URETHRAL SPHINCTEROTOMY plays an important rôle in treating male patients with obstructed neuropathic bladder (O'Flynn, I9\%2; Ross et al., I976). Unfortunately the widely practiced technique of incising the sphincter bilaterally at 3 and 9 o'clock is associated with an appreciable incidence of loss or diminution of penile erections postoperatively (Schoenfeld et al., I974; Kiviat, I975; Thomas, I976; Yalla et al., I977). Two small series have suggested that the risk of this complication is reduced by single anteromedian incision of the sphincter (Yalla et al., I977, Golji, I980) and we report here our experience with this technique.

\section{Patients and Methods}

One hundred and four male patients with neuropathic bladder have undergone anteromedian sphincterotomy in our Unit from June I977 to March I982. Ten are excluded from the series because of death (six) or loss to follow-up (four). The ages of the patients at the time of operation ranged from I 4 to 69 years (average 35 years). Eighty-three suffered from acquired lesions of the cord ( 79 traumatic, 4 non-traumatic) and I I from congenital cord lesions, and these various conditions had been present for periods of 4 months to 49 years (average $9 \cdot 6$ years) prior to spincterotomy.

The patients were assessed pre-operatively by intravenous urography and by combined video-urodynamic studies (Thomas et al., I975), and the indications for sphincterotomy were:

I. Marked detrusor-spincter dyssynergia, often associated with dilated upper renal tracts (67 cases).

2. Difficulty in voiding in patients with acontractile bladders in whom the obstruction lay at the level of the external urethral sphincter (22 cases). 
3. In tetraplegic patients with autonomic dysreflexia precipitated by voiding ( 5 cases).

Single anteromedian incision of the sphincter was made with a knife electrode on low blended diathermy, commencing just proximal to the level of the verumontanum and continuing distally to the bulbar urethra. In 35 patients, the bladder neck was also incised or resected. The bladder was drained for a few days postoperatively with a urethral catheter. No serious problems were encountered with primary or delayed haemorrhage nor were there any other significant complications in the immediate post-operative period. Because of incomplete division of the sphincter, nine patients required a second procedure.

\section{Results}

Of the 94 patients followed up, 20 had had complete loss of erections preas well as post-operatively (Table I); the majority (I3) had an acontractile bladder with absent conus reflexes.

TABLE I

Patients without erections prior to sphincterotomy

\begin{tabular}{cc}
\hline Neurological level & Number \\
\hline Above D5 & 2 \\
D5-Dio & $6($ I $)$ \\
Below Dio & I2 (4) \\
\hline
\end{tabular}

Figures in brackets indicate numbers with incomplete cord lesions.

TABLE II

Post-operative status of 74 patients with erections prior to sphincterotomy

\begin{tabular}{llccc}
\hline $\begin{array}{c}\text { Neurological } \\
\text { level }\end{array}$ & $\begin{array}{c}\text { No } \\
\text { change }\end{array}$ & $\begin{array}{c}\text { Erections } \\
\text { abolished }\end{array}$ & $\begin{array}{c}\text { Erections } \\
\text { diminished }\end{array}$ & $\begin{array}{c}\text { Erections } \\
\text { improved }\end{array}$ \\
\hline Above D5 & $26(8)$ & - & $5(\mathrm{I})$ & $4(\mathrm{I})$ \\
D5-DiO & I I & - & - & - \\
Below Dio & $22($ IO) & $3(\mathrm{I})$ & $2(\mathrm{I})$ & I \\
Total & 59 (I8) & $3(\mathrm{I})$ & $7(2)$ & $5(\mathrm{I})$ \\
\hline
\end{tabular}

Figures in brackets indicate numbers with incomplete cord lesions.

Of the remaining 74 cases (Table II), I 5 have experienced a change in penile erections post-operatively, among which are five who claim an improvement, four of these being tetraplegic with a neurological level at or above C6.

Ten patients ( 13.5 per cent) report their erections to have been adversely affected by sphincterotomy and since follow-up has been for more than a year in all cases, this change is likely to be permanent.

In seven patients ( 9.5 per cent), erections have become diminished, either in strength, frequency or both, and six of these had reflex voiding with detrusor-sphincter dyssynergia. One patient experienced a change in erections only after his second sphincterotomy, while in another case the problem only became manifest 3 months post-operatively and it is doubtful if the procedure can be implicated in this latter instance.

All three patients (4 per cent) with complete loss of erections had a neurological level at or below D I I and had dilated upper renal tracts. One 
had reflex voiding and two acontractile bladders. In one case there had been an 8 week period of priapism immediately pre-operatively and his subsequent loss of erections may derive from this rather than from the sphincterotomy itself.

The incidence of adverse effects of sphincterotomy on erections was not influenced by whether there was or was not an additional bladder neck procedure.

\section{Discussion}

It remains uncertain as to why endoscopic urethral sphincterotomy may affect penile erections. Patients with low cord lesions, especially those with absent conus reflexes, are liable to lose erections either directly as a result of their neurological disease or later following sphincterotomy. In our experience patients with high lesions, above $\mathrm{D}_{5}$, are at risk of experiencing diminished erections after sphincterotomy while those with mid-dorsal lesions are relatively free from this complication.

Apart from the neurological status of the patient, local factors pertaining to the sphincterotomy itself are clearly important. Injury to the corpus spongiosum was implicated by Schoenfeld et al. (1974). Kiviat (1975) suggested that 3 and 9 o'clock incisions were liable to damage the laterally placed branches of the internal pudendal arteries to the corpus spongiosum while Yalla et al. (I977) postulated trauma to the nerve bundles which accompany these vessels as an additional factor. Certainly published material indicates that 3 and 9 o'clock incisions are more likely to adversely affect erections than incision(s) made in front of or behind this axis (Table III). It is also suggested that the technique as well as the siting of the incision(s) may be important (Jameson, I982).

In our hands although the incidence of erectile complications has fallen

TABLE III

Reported effects of urethral sphincterotomy on penile erections

\begin{tabular}{|c|c|c|c|c|c|}
\hline \multirow[t]{2}{*}{ Author(s) } & \multirow[b]{2}{*}{$\begin{array}{c}\text { Type of } \\
\text { sphincterotomy }\end{array}$} & \multirow{2}{*}{$\begin{array}{c}\begin{array}{c}\text { Before } \\
\text { sphincter- } \\
\text { otomy }\end{array} \\
\begin{array}{c}\text { Number with } \\
\text { erections }\end{array}\end{array}$} & \multirow[b]{2}{*}{$\begin{array}{l}\text { Erections } \\
\text { abolished }\end{array}$} & $\begin{array}{l}\text { After } \\
\text { sphincter- } \\
\text { otomy }\end{array}$ & \multirow[t]{2}{*}{ Total } \\
\hline & & & & $\begin{array}{l}\text { Erections } \\
\text { diminished }\end{array}$ & \\
\hline $\begin{array}{l}\text { Schoenfeld } \\
\text { et al. (1974) }\end{array}$ & $3 \& 9$ o'clock & 2 I & & $3(14 \%)$ & $8(3)-2)$ \\
\hline Kiviat (I975) & $3 \& 9$ o'clock & 15 & $5(33 \%)$ & $6(40 \%)$ & I I $(73 \%)$ \\
\hline Thomas (I976) & $3 \& 9$ o'clock & 43 & $9(2 \mathrm{I} \%)$ & I $5(35 \%)$ & $24(56 \%)$ \\
\hline $\begin{array}{l}\text { Yalla } \\
\text { et al. (I } 977 \text { ) }\end{array}$ & & 28 & & & \\
\hline Golji (I980)* & $3 \& 9$ o'clock & $46(?)$ & $8(17 \%)$ & & \\
\hline $\begin{array}{l}\text { Kiviat（1975） } \\
\text { Yalla }\end{array}$ & I \& I I o'clock & I4 & 0 & I $(7 \%)$ & I $(7 \%)$ \\
\hline et al. (1977) & Anteror & I 4 & 0 & 0 & 0 \\
\hline Golji (I980)^ & Anteromedian & $7(?)$ & 0 & $?$ & $?$ \\
\hline Present series & Anteromedian & 74 & $3(4 \%)$ & $7(9 \cdot 5 \%)$ & $10(13.5 \%)$ \\
\hline Jameson (I982) & $5 \& 7$ o’clock & 90 & 0 & & 0 \\
\hline
\end{tabular}

^Numbers of patients with no erections pre-operatively and diminished erections postoperatively not quoted. 
considerable since changing from 3 and 9 o'clock incisions (Thomas, I976) to single anteromedian incision, there still remains an appreciable risk; even if the two dubious cases are excluded, eight (I I per cent) patients undoubtedly had their erections adversely affected by anteromedian sphincterotomy. This contrasts with Jameson (I982) who found no loss of sexual potency in 90 patients undergoing 5 and 7 o'clock sphincterotomy. This discrepancy is puzzling. Technique of incision does not appear to be a factor. It may be that 5 and 7 o'clock incisions enjoy some inherent advantage over anteromedian incision although there is no obvious reason why. Case selection may be a factor since Jameson's (I 982) series contains a higher proportion of patients with cervical and dorsal (low risk) lesions than ours. Finally the discrepancy may partly derive from terminology; whereas Jameson (I982) refers purely to sexual potency, we deal only with erections per se. There were patients in our series who had erections (including some where these were lost or diminished post-operatively) but which were never adequate for sexual intercourse.

At all events it seems clear that if the risk of sphincterotomy adversely affecting penile erections is to be minimised, then 3 and 9 o'clock incisions should be avoided.

\section{RÉSUMÉ}

Dans un série de 94 malades avec une vessie neuropathique de lesquels antéroménm urètral sphinctérotomie était exécuté, 20 n'avaient pas des érections pénile avant chirurgie. De les autres 74 cas, $7(9.5 \%)$ avaient des érections diminués post-opérativement, et $3(4 \%)$ n'avaient aucuns d'érections. C'est considéré que le risque de cette complication s'est attenuée avec antéromédiane sphinctérotomie que avec bilatéral sphinctérotomie (à 3 et 9 heures montre en main).

\section{ZUSAMMENFASSUNG}

In einer Reihe von 94 Patienten mit neuropathischer Harnblase wurde anteromediale Durchtrennung des Harnröhrensphinkters durchgeführt; 20 von diesen hatten keine Peniserektion vor der Operation. Von den übrigen 74 Fällen, $7(=9.5 \%)$, hatten reduzierte Erektion nach der Operation, in 3 Fällen $(=4 \%$ ) waren diese gänzlich abwesend. Es wird daher angenommen, dass das Risiko dieser Komplikation mit anteromedialer Durchtrennung seltener ist als mit der beiderseitigen Sphinkerotomy in der 3 und 9 Uhr Lage.

\section{REFERENCES}

GoljI, H. (1980). Urethral sphincterotomy for chronic spinal cord injury. F. Urol., I23, 204-207.

JAMESON, R. M. (1982). The long-term results of transurethral division of the external urethral sphincter in the neuropathic urethra with reference to potency. Paraplegia, 20, 299-303.

KIVIAT, M. D. (I975). Transurethral sphincterotomy: relationship of site of incision to post-operative potency and delayed haemorrhage. F. Urol., 114, 399-40I.

O'FLYNN, J. D. (1972). External sphincterotomy for the relief of outlet obstruction in the neurogenic bladder. Paraplegia, 10, 29-36.

Ross, J. C., Gibbon, N. O. K. \& Sunder, G. S. (1976). Division of the external urethral sphincter in the neuropathic bladder: a twenty years' review. Brit. F. Urol., 48, 649656.

Schoenfeld, L., Carrion, H. M. \& Politano, V. A. (1974). Erectile impotence: complication of external sphincterotomy. Urology, 4, 68 I-683.

Tномаs, D. G. (1976). The effect of transurethral surgery on penile erections in spinal cord injury patients. Paraplegia, 13, 286-289.

Thomas, D. G., Smallwood, R. \& Graham, D. (I 975). Urodynamic observations following spinal trauma. Brit. F. Urol., 47, I6I-175.

Yalla, S. V., Fam, B., Gabilando, F. B., Jacobs, S., DiBenedetto, M., Rossier, A. B. \& GitTER, R. F. (I977). Anteromedian sphincterotomy: technique, rationale and complication. F. Urol., I1 7, 489-493. 